
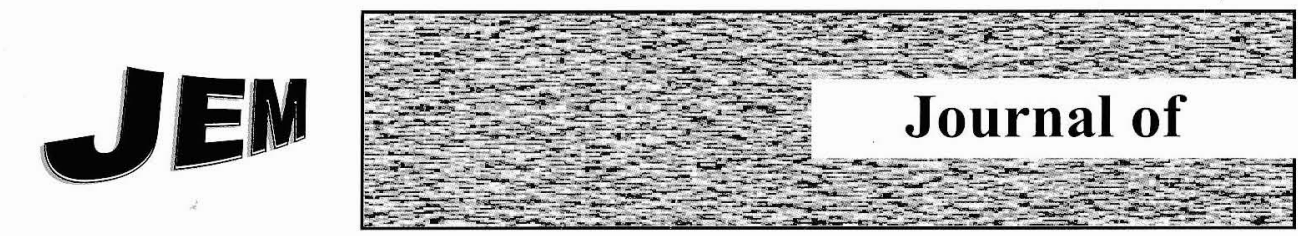

EDucational Management

A Bi-annual Publication of

THE INSTITUTE FOR EDUCATIONAL PLANNING AND ADMINISTRATION

(IEPA)

University of Cape Coast, Ghana

ISSN 0855 - $3343 \quad$ Vol. $6 \quad$ Nov. 2012 


\title{
Determining Polytechnic Teachers' Professional Development and Curricular Quality through Collaborative Curriculum Design
}

\author{
Marie Afua Baah Bakah \\ Joke Voogt \\ Jules Pieters
}

\section{Abstract}

In this study collaborative curriculum design is addressed as an effective method for the continuing professional development of teachers in a polvtechnic in Ghana during curriculum reform. Three design teams have been working to update engineering syllabuses to commensurate contemporary industrial skill demands as well as update their own knowledge in their subject areas for fourteen weeks. They embarked on industrial visits, incorporated relevant information in their courses and conducted teaching try-outs. Mixed methods were employed for data collection during design activities. Results indicated that leachers updated their domain knowledge and skills, design teams improved teacher collaboration while teacher ownership of and commitment to quality curriculum increased. Furthermore, teaching try-outs of updated courses were a success from both teachers and students perspectives. It was concluded that the relational nature of the interdependencies between the social and individual contributions to curriculum design illuminates the fabric of teachers' continuing professional development.

\section{Introduction}

Curriculum renewal is a complex undertaking which requires the quality of two related processes: curriculum development and teacher professional development (PD) for it to be successful (Fullan, 2007). Recent insights in curriculum reform point to the need to increase the active involvement of teachers to promote ownership, commitment and successful implementation (Borko, 2004). The curriculum reform situation in Ghana's polytechnics, which have metamorphosed over the past 20 or more years, has called, as from these recent insights, for the involvement of teachers in curriculum design; updating Higher National Diploma (HND) programmes and designing Bachelor of Technology (B. Tech.) programmes. Having been upgraded to higher education institutions, polytechnics in Ghana provide higher technical and vocational education and training leading to the award of HND and B. Tech. in business and management, applied arts and sciences and engineering. The problem researched in this study is related to polytechnic teachers' PD as they embark on rigorous curriculum design due to the polytechnics' upgrading (Gervedink Nijhuis, Bakah \& Akomaning, 2009; Nsiah-Gyabaah, 2005). The upgrade of polytechnics into tertiary institutions called for a curriculum 
reform and the maintenance of competent teachers. One key area of concern for PD as expressed by polytechnic teachers and management in Ghana is for the former to update their knowledge and skills in their subject areas through embarking on industrial attachment (Bakah, Voogt \& Pieters, in press) to effectively contribute to curriculum design. Furthermore, as technology is fast advancing, polytechnic teachers see the need to continuously pursue relevant knowledge to improve on their professional competence and be able to update their courses (Bakah, Voogt \& Pieters, in press). As widereaching change takes place in society new kinds of work are emerging and new kinds of vocational curricula are needed to prepare citizens for employment in these contexts. When teachers are co-designers of new curricula, the curriculum development and teacher PD processes become intertwined: curriculum development activities can lead to increased professional development. On the contrary, increasing professional expertise can lead to further improving curriculum development as was revealed in a study by Bakah, Voogt and Pieters (2012) that showed that collaborative curriculum design (CCD) through design teams (DT) enabled active learning, collaboration as well as dialogue on subject matter among teachers, and was a useful means for the PD process. In this study we explore the impact of CCD in DTs on curriculum quality and teachers' professional development in the polytechnics. Studies have revealed the benefits of CCD in DTs (Millar et al., 2006; Simmie, 2007).

\section{Collaborative curriculum design and design teams}

CCD is gradually gaining ground in education as a promising way to create teacher ownership by involving them in curriculum innovation (Borko, 2004; Desimone, 2002). CCD processes have the potential to contribute to the PD of the teachers involved as well (Borko, 2004). By collaboratively designing, subject matter interactions occur which can be used as learning opportunities and the combination of doing and reflecting can enhance PD (Penuel et al., 2007). According to Supovitz (2002) much of the attention and widespread use of research on teams in order to improve practice and instruction comes from the organizational theories on group practice and communities in the workplace. Collaboration in teams or communities is presented as an effective response to increasing change and a knowledge based workforce (Handelzalts 2009). By collaborating, professionals pool their knowledge and can together create new knowledge.

Teachers' teams usually described in literature (i.e. professional learning communities, communities of practice) mostly focus on improving the teaching process through the PD of the teachers (Handelzalts, 2009). In the case of the DTs, PD or building of cohesion among teachers are seen as outcomes in a design process. The theoretical basis for the formation of DTs lies in the findings of a number of studies (e.g. Lieberman \& Miller 2005) in which teaching is viewed as a complex intellectual activity with the inherent drive of experienced teachers to fulfil their learning, social and 
intellectual needs as part of the process to realise their full potential. The DT concept provides teachers with a creative space to reconsider the teaching of their subject, the intellectual stimulus of working together and the challenge to move the thinking forward. In this way, teachers are invited to become curriculum makers (Simmie, 2007). According to Handelzalts (2009) a DT is a group of at least two teachers, from the same or related subjects, working together on a regular basis, with the goal to redesign and enact (a part of) their common curriculum. It is one means by which teachers can collectively participate in curriculum design, fulfil their learning, social and intellectual needs and are effective in bringing about teacher PD (Mishra. Koehler \& Zhao, 2007: Penuel et al., 2007) and curriculum innovation (Mishra, Kochler \& Zhao, 2007).

\section{Collaborative curriculum design in this study: Structure and activities}

The collaborative curriculum design activities took fourteen-weeks and included an introductory workshop, CCD activities, industrial visits and teaching try-outs. The introductory workshop, which was held in the first week, oriented teachers on CCD in teacher DTs. The first author as researcher was the main facilitator at the workshop and throughout the study. Starting from the second week, teachers in three teams, based on commonality in subject areas, worked collaboratively to update their courses to suit current technological practices in industry. The teachers visited industry in teams to acquire relevant information to make their courses more practical and relevant in content. The Automobile team visited Caterpillars and Quansah Motors (representatives of Toyota Ghana) in Takoradi and Mechanical Lloyd (representatives of BMW) in Accra, the Production team visited Gratis Foundation and Westing Castings in Takoradi. Ghana Grid Company Limited (GRIDCo) and Takoradi International Company at Takoradi and Aboadze respectively were the industrial locations visited by the Electrical team. They were exposed to several technologies regarding their area of study. In many ways, this course redesign was a typical team experience for the teachers; for the most part, the teams worked at their own pace to complete the redesign of the courses. During the thirteenth and fourteenth weeks, teachers conducted teaching try-outs of the updated courses which were subsequently evaluated by the students. To understand how DTs impact on the curriculum and teacher professional development, the following research question is addressed in this study:

What is the impact of DTs on teacher professional learning and on curriculum practices?

\section{Methods}

Mixed methods in a multicase study embedded design (Yin, 1993) was applied with the DTs as the three cases, and teachers and students as units of analysis. The study investigated teachers' perceptions regarding their participation in DTs, their learning from co-design activities and changes in classroom practice. Students' evaluation of the teaching try-outs 
helped to assess the impact of the updated courses.

\section{Participants}

\section{Teachers}

Overall, 16 teachers (all males), addressed in this study by pseudonyms, from the faculty of engineering at a polytechnic in Ghana took part in the study based on their availability as fulltime teachers and upon recommendation by their heads of department. The teachers were grouped into three teams which are Automobile, Production and Electrical DTs. Background characteristics of the teachers are provided in Table 2. The polytechnic was purposefully selected since it is situated in a relatively industrialised region of Ghana.

Table 1 Background characteristics of teachers

\begin{tabular}{llllll}
\hline Design team & $\begin{array}{l}\text { Teachers } \\
\text { (pseudonyms) }\end{array}$ & Age & $\begin{array}{l}\text { Highest } \\
\text { academic } \\
\text { qualification }\end{array}$ & $\begin{array}{l}\text { Years of } \\
\text { teaching at } \\
\text { polytechnic }\end{array}$ & $\begin{array}{l}\text { Number of } \\
\text { students }\end{array}$ \\
\hline $\begin{array}{l}\text { Automobile } \\
(n=5)\end{array}$ & $\begin{array}{l}\text { Edem } \\
\text { Atsu }\end{array}$ & 46 & Master's & 1 & Year 1: \\
& Kwame & 28 & HND & 15 & 144 \\
& Wesley & 32 & HND & 3 & Year 2: 38 \\
Production & Sage & 51 & Bachelor's & 7 & \\
$(n=5)$ & Douglas & 69 & Bachelor's & 21 & Year 1: \\
& Michael & 63 & Master's & 3 & 104 \\
& Robert & 55 & Master's & 6 & Year 2: \\
Electrical & Archi & 52 & Master's & 3 & 106 \\
$(n=6)$ & Tony & 48 & HND & 23 & Year I: \\
& George & 64 & HND & 17 & 151 \\
& Ben & 26 & Bachelor's & 2 & Year \\
& Cephas & 39 & Master's & 3 & $2: 120$ \\
& Angelinos & 32 & HND & 3 & \\
& David & 27 & Master's & 3 & \\
& Antoine & 26 & HND & 2 & \\
\hline
\end{tabular}

Note: HND, higher national diploma, below bachelor level.

\section{Instruments}

Teachers also responded to closeended 5 point Likert-scale questionnaire items, with 1 is strongly disagree to 5 is strongly agree on their perceptions of industrial attachment, $C C D$, teaching try-out, learning in DTs and their perceptions of DTs before and after the PD programme. There were five categories of semi- structured interview data collected from each teacher to find out their experiences during the following DT activities: industry visits, course update, teaching try-outs, perceptions of DTs and teacher learning in DTs. On average, each interview lasted 45 minutes and was audio taped. A logbook was kept by the first author in order to document the process of teachers working in the DTs.

Questionnaires were administered to students after the teaching try-out of 
updated courses. The questionnaires consisted of 17 items on students' perceptions and experiences with the courses taught. Possible answers to all items were on a five point Likert-scale ( $1=$ strongly disagree to $5=$ =strongly agree). After running factor analysis using PASW Statistics, two constructs obtained were presentation $(=0.95)$ and clarity $(=0.93)$ for student responses. Presentation in this study refers to the practice of showing and explaining content of the topic to the students and clarity denotes the practice of making content of the topic clear for students' comprehension of the concepts.

\section{Data Analysis}

Comparison of teachers' perceptions of DTs before and after the PD programme employed the PASW Statistics Mann-Whitney U nonparametric test on assumption that the population cannot be assumed to be normally distributed. Effect size was calculated using Cohen's $d$ (Cohen, 1988) tentative benchmarks for the interpretation of effect sizes being $\mathrm{d}=0.2$ a small, $\mathrm{d}=0.5$ a medium and $\mathrm{d}=0.8$ a large effect size. For students' responses an independent sample ttest was computed to find out whether significant differences existed regarding the experiences of partici-pants and non-participants in the teaching try-out in terms of the sub-scales presentation and clarity. Cohen's $d$ (Cohen, 1988) was calculated to find out the extent of the differences. A one-way ANOVA test was conducted to evaluate the extent to which differences exist between the participants (Automobile, Production and Electrical HND students) perceptions of the lesson they had in terms of presentation and clarity.

All interviews were transcribed and coded using codes generated from the study. The coding schemes (Miles \& Huberman, 1994) were labelled: industrial attachment evaluation, course update evaluation, teaching try-out appraisal, perceptions of DTS and teacher learning in DTS. Atlas-ti software version 6.2 was used for the coding of all the interview data. Intercoder reliability (Lombard, Snyder-Duch \& Bracken, 2002) was calculated using a random sample of 8 interviews from 16 teachers. There were two coders including the first author of this article. The intercoder reliability using Cohen's kappa (k) was 0.91 . Information recorded in the logbook was analysed qualitatively using data reduction technique. Major themes were identified and clustered (Miles \& Huberman, 1994).

\section{Results}

\section{Teachers' professional learning in DTs}

Acquisition of knowledge and skills during visits to industry: Teachers' evaluation of the industrial attachment revealed that all the teams found the visit relevant. The overall means for acquisition of knowledge and skills (mean $=4.37, \mathrm{SD}=0.30$ ) was high. Further details were provided by the teachers regarding the knowledge and skills they acquired at the industry. Michael in the Production team confessed that he personally had not encountered foundry work at the industry so it was a new experience for him. Antoine (Electrical team) expressed his excitement at some 
observations he made for the first time:

"It was really interesting to see for the first time that the optical wire actually gets through the optical ground wire and from there it goes through the all diametric self supporting system ... to avoid any interference, that is, disturbance of carrier signals".

Atsu (Automobile team) also stated that, "It was the first time we saw the torque convertor and its components even though we have always been mentioning it in teaching". Most of the Automobile teachers appreciated the tremendous progress being made at the industry: eschewing trial and error process, precision in their work, ability to relate to them technically and their knowledge about the systems. Apart from the vehicle engines, the changes taking place in the cars mostly had to do with the electronic system which they were introduced to. The Electrical team found it very interesting to learn about the new communication system using the optical fibre. Some of the teachers realised that even the very simple maintenance procedures that they taught students had a shortfall and so were pleased to learn what the real industrial practices are. For instance Edem of the Automobile team indicated that:

"...I discovered that most of the components of the tractor are frozen before being used. Also detergents are used to clean machinery after it is disassembled so that exact portions for wear and tear are detected. Meanwhile what we teach is for a part to be replaced when they are not working but did not realize that dirt could be the problem".

Having observed teachers' admissions concerning their experiences at the industry, the knowledge they acquired on contemporary industrial operations was detailed and extensive as certain principles became clearer and for others some operations, machines and maintenance procedures were seen for the first time. Apart from resource persons' briefings, the teachers acquired some practical skills at the industry as a result of learning about machines and equipment and in some cases practicing their use or operating them through a hands-on training.

\section{Co-design in DTs: During the course} update certain areas and topics were selected for update based on team discussions regarding challenges of teaching the courses: unavailability of certain equipment for practical lesson demonstrations, obsolete equipment, limited knowhow on operations, verification on certain maintenance procedures, upgraded equipment not incorporated, teachers' and students' challenges with the course, current technological advancements and so on. Results of teachers' perception of the CCD activities showed a generally high means and standard deviations (mean $=4.37, \mathrm{SD}=0.22$ ) for all the DTs.

All the teams engaged in identifying need areas for the courses they selected for update. With the syllabus, they were able to identify the areas of interest and according to Douglas 
(Production team) “... we identified need areas in the syllabus ... where in my opinion knowledge was weakest". Ensuring curriculum relevance and quality was the target of the teams as Wesley (Automobile team) informed that, "We are rejuvenating the practical component of our courses and I find it very relevant". Teachers found the industrial visit a healthy one to being abreast with the current systems so as incorporate relevant topics in the syllabus. Angelinos (Electrical team) was of the view that the design activities compelled him to be responsible for quality of the curriculum. It was necessary for the teams to align their syllabus to what is existent in the industries since employers need graduates with readily available useful skills. Tony in the Production team remarked, "It helps us to know what we should actually teach the students". Apart from enhancements to existing curriculum, teachers gained some basic (curriculum) design skills. They developed the expertise in analysing the various components of the course, including theory and practicals, verify/authenticate information and incorporating relevant knowledge in syllabus.

\section{New approaches to teaching in} teaching try-outs: During the teaching try-out by the Automobile team pictures in PowerPoint slides were used to explain the maintenance of hydraulic systems and board diagnostics. The Electrical team took their students through the lesson on synchronisation and tap changing using motion pictures, whilst hydraulics and joinery methods were taught by the Production team using
PowerPoint slides. The teachers evaluated the teaching try-outs with responses to items such as: The lesson was generally interesting; Students understood the topic and explanation on equipment better; I explained concepts better than previously; Students had a clear and vivid picture of equipment; Students liked the mode of presentation; I applied skills acquired in industry and so on. Overall means showed that teachers appreciated the teaching try-out of their courses (mean $=4.71, \mathrm{SD}=0.20$ ) in terms of imparting useful information to students in their lessons, indicating the success of the teaching try-outs.

The teaching try-outs were opportunities for teachers to teach the upgraded course during which they communicated what they had learned from the industry. It sharpened teachers' skill of imparting knowledge obtained from industry. They had gained confidence in the teaching of the updated courses due to knowledge they acquired and shared in DTs. Furthermore, teaching what is ongoing at the industry instead of working on the same old laboratory equipment in the polytechnic made the teaching livelier.

\section{Updated curriculum and its quality}

Teacher perspectives: During the teaching try-out, teachers revealed their experiences with teaching the updated courses. Having added new content to improve the quality of their courses was satisfying for the teachers. Revealing his teaching try-out experiences, Ben (Electrical team) indicated that:

"Earlier, we used only the small types of 
transformers meant for power distribution purposes but they (students) haven't seen a transmission transformer which is also called the power transformer so having seen it; students were very keen and interested in the lesson".

Teaching students what is existents at the industries gave a sense of meaning to the curriculum while teachers had the satisfaction that students learnt something more relevant. According to Sage (Automobile team), showing students components of the torque converter was a new thing in class because earlier on he only mentioned it. This boosted his confidence compared to earlier lesson. Students also found the lesson interesting, and easy to understand. Robert (Production team) was confident about imparting relevant knowledge to students on how blow holes which are casting defects are detected using ultrasonic sound detectors. Robert said that, "These are transformations that we have not included in our earlier teaching".

Student perspectives: Students were generally fascinated by the lessons and stated that viewing clear and vivid images of equipment and industrial operations gave them a very broad knowledge of the topic and was a very good idea. The mode of delivery sustained their interest throughout the lessons. They were generally of the view that concepts became clearer and things they had to imagine or view diagrammatically in books were seen real, thus such presentation should be extended to other topics. The students evaluated the lessons and further confirmed their experiences which can be found in the results listed in Table 2. The overall means of aspects of the lesson reported by the students were very high; presentation (Mean $=4.21$, $\mathrm{SD}=0.47)$ and clarity $($ Mean $=4.04$, $\mathrm{SD}=0.56)$.

\section{Table 2 Overall means for students' experiences}

\begin{tabular}{lcccccc}
\hline $\begin{array}{l}\text { Students } \\
\text { Experiences }\end{array}$ & $\begin{array}{c}\text { Non-Participant } \\
(n=293)\end{array}$ & \multicolumn{2}{c}{$\begin{array}{c}\text { Participant } \\
(n=370)\end{array}$} & Sig. & $\begin{array}{c}\text { Effect } \\
\text { Size }\end{array}$ \\
& $M$ & SD & M & SD & & \\
\hline Presentation & 2.96 & 1.08 & 4.21 & .47 & $.0001^{*}$ & 1.50 \\
Clarity & 2.85 & 1.00 & 4.04 & .56 & $.0001^{*}$ & 1.47 \\
\hline
\end{tabular}

Note: $M$, means; SD, standard deviation; 1 , strongly disagree to 5 , strongly agree; $* \mathrm{p}<0.05$.

A one-way ANOVA test was conducted to evaluate the extent to which differences exist between the participant perceptions for the course they took. It was revealed that significant differences existed across lessons for Automobile, Production and Electrical student groups in terms of both subscales presentation $(F=9.05, \quad p=0.0001)$ and clarity $(F=13.18, p=0.0001)$. Using the Tukey HSD procedure, multiple comparisons between the three programmes were made to evaluate the pairwise differences among the means for the subscales. With respect to the lesson 
for Production and Automobile students, pairwise significant differences (difference in means $=.26$, $p=0.0001$ ) were present. Also, pairwise significant differences (difference in means $=0.17, p=0.007$ ) were there regarding the lessons for Production and Electrical students. Apparently the relatively low rating of presentation for the Production lesson could be attributed to the somewhat poor images on the PowerPoint slides used in class due to inadequate illumination of the workshops in Westing Castings (an industry). Furthermore the extra high lights produced through welding affected visibility. Regarding clarity, pairwise differences existed between showed in terms of the Electrical and Automobile/ Production lessons (resp. difference in means $=0.24, p=0.001$; difference in means $=0.33, p=0.0001$ ). The higher appreciation of the Electrical lesson regarding clarity could be attributed to the seemingly abstract nature of the topic which was taught previously without illustrations. As a result the intervention might have brought a great distinction between the way the topic 'synchronisation' was taught and therefore liked by the students.

\section{Teachers ${ }^{\prime}$ perceptions of DTs as a $P D$ arrangement}

Survey data from teachers showed their perceptions of DTs before and after engaging in its activities. Results indicate that a significant difference $(p<0.05)$ existed between teachers' perceptions before and after the PD activities with a corresponding extremely large effect sizes ranging from 2.25 to 3.54 . The overall significance $(p=0.0001)$ and effect size (3.28) were both very high.
Dts were a useful means of bringing teachers together and a learning ground for many. Kwame (automobile team) was of the view that, "Participating in DTs been a real eyeopener. There were ideas that never crossed my mind until my being in this team". Through contributions from team members, a lot of ideas flowed for course update and teacher professional development. Ben (Electrical team) confirmed this saying, "Being in a group also promotes strength than being single". According to David (Electrical team), DT was very useful because whenever teamwork takes place there is always a brainstorm and something useful comes out of it due to the various experiences everyone has, therefore, he maximised the chance to learn from others. Teamwork gave the opportunity for teachers to speak with themselves, talk about issues that concern them, teaching and industry work. DT was a learning ground for teachers during $\mathrm{CCD}$ as evidenced in their questionnaire data. Results from the survey indicated that across all the teams, teacher learning occurred (mean $=4.48, \mathrm{SD}=0.36$ ).

In spite of the positive results from the teachers on their DT experiences, they encountered certain challenges during teamwork which include conflicting timetables affecting meeting times and managing students' time during teacher absence during industry visit. However, it was suggested by the teachers that DT activities should be maintained in their departments and initiated in other departments in the polytechnic for curriculum design and teacher professional development. On the whole, they want it integrated into the polytechnic structure to enable teacher learning and collaboration. 


\section{Discussions and conclusions}

This study sought to examine the impact of collaborative design activities on teacher PD and curricular quality among polytechnic teachers. The DT concept aimed to strengthen teamwork among colleagues in the same subject area as they embark on updating their knowledge and courses. The teachers' account of their experiences with working collaboratively in DTs has informed this study. To a very large extent, teachers showed dedication during all aspects of the design process and developed their knowledge and skills in the process. The discovery of current information on content in DTs improved their practical skills as supported by the social learning perspective on teachers' PD that teamwork is a powerful new element that provides a useful corrective to overly individualistic approaches to teacher development (McArdle \& Coutts 2010). By collaboratively designing, the teachers gained the skill of interacting with each other on content as is the view of Penuel et al. (2007) that interactions through doing and reflecting can enhance $\mathrm{PD}$. The teaching try-outs generated changes in teacher behaviour which included: greater confidence; enhanced beliefs among teachers of their power to make a difference to students' learning; development of enthusiasm for collaborative working, greater commitment to changing practice and willingness to try new things.

Collaboration in DTs enhanced teacher learning and increased subject matter dialogue which confirms the findings of Borko (2004) that CCD processes have the potential to contribute to the PD of the teachers involved. Teacher learning and PD was impressive during CCD as similarly was the case in the study of Mishra, Koehler and Zhao (2007) and Penuel et al. (2007). The study of Borko (2004) suggests that PD interventions that make extensive use of teacher collaboration are particularly successful in supporting teacher learning. Teacher learning impacted positively on their classroom practices as a result of redressing particular challenges in their courses and improving curriculum quality. Andrews and Lewis (2007) also found that where teachers work collaboratively, it not only enhanced their knowledge base, but also had a significant impact on their classroom work. This was evident in the teaching try-out where students appreciated the knowledge they acquired, a finding similar to that of Millar et al. (2006) whose studies with DTs to develop research-based classroom materials resulted in increased student's motivation. DT in this intervention clearly appeared to be a valuable approach to teamwork among polytechnic teachers for them to update their knowledge and skills and update their courses (cf. Millar et al., 2006; Simmie, 2007). Despite the few initial challenges that teachers encountered in DTs combining design activities with already heavy teaching workloads, their teamwork to advance ideas had enormous returns making it a promising strategy for their knowledge update. The result of this case study basically confirms the findings of a similar study conducted in another polytechnic in Ghana by the authors of this work (anonymous). Therefore, although generalising this study worldwide might not be possible, results from the two studies confirm 
that CCD is a useful means for teachers' PD apart from ensuring curriculum quality. Consequently, the findings here have far reaching implications for polytechnic education in Ghana and sub-Saharan Africa.

In conclusion, findings suggest that teachers improved their knowledge during CCD. DT is a worthwhile undertaking for teachers' PD during CCD. Findings from this study authenticate the valuable characteristics of collaboration among teachers as a useful means for teacher interaction and teacher learning and DTs served that purpose well. Thus this study provides insights into engaging teachers in teamwork for their PD. It also highlights the importance of engaging teachers in the update of their own courses as well as making them conscious of maintaining curriculum quality and relevance. $\mathrm{CCD}$ encourages grass root participation in making curricular decisions and instils a sense of ownership among teachers. It becomes evident from the implications of this study that it is worthwhile to connect teachers through teamwork and allow their reflections on current practices and promote creativity. This study provides evidence of some characteristics that learning comm-unities exhibit as indicated by Bolam et al. (2005) such as shared values and vision; collective responsibility for pupils' learning; collaboration focused on learning; individual and collective professional learning; reflective professional inquiry; openness, networks and partnerships; inclusive membership; mutual trust, respect and support. Consequently, findings demonstrate teacher learning in their work environments and the emphasis to and promote quality teaching and learning. The relational nature of the interdependencies between the social and individual contributions illuminates the fabric of teachers' PD and subject matter discourse.

\section{References}

Andrews, D \& Lewis M 2007. Transforming practice from within: The power of the professional learning community. In: Stoll L \& Louis K S (eds.). Professional learning communities: Divergence, depth and dilemmas. Maidenhead: Open University Press.

Bakah, M. A. B., J. Voogt, \& Pieters, J. (in press). Curriculum reform and teachers' training needs: the case of higher education in Ghana. International Journal for Training and Development, doi: $10.1111 / \mathrm{j} .1468-2419$. 2011.00389.x.

Bakah, M. A. B., J. Voogt, and Pieters, J. (2012). Updating polytechnic teachers' knowledge and skills through teacher design teams in Ghana. Professional Development in Education, 38(1), 724.

Bolam R A McMahon, Stoll L, Thomas S, Wallace M, Greenwood A, Hawkey $K$, Ingram $M$, Atkinson A \& Smith M 2005. Creating and sustaining effective learning communities. Research Brief No. RB637 London: Department for Education and Skills.

Borko H 2004. Professional development and teacher learning: Mapping the terrain. Educational Researcher; 33:3-15. 
Cohen J 1988. Statistical power analysis for the behavioral sciences. (2nd ed.) Hillsdale, NJ: Lawrence Erlbaum Associates.

Desimone L 2002. How can comprehensive school models be successfully implemented? Review of Educational Research, 34:2-14.

Fullan M 2007. The new meaning of educational change. New York: Teachers College Press.

Gervedink Nijhuis C, Bakah M A B \& Akomaning E 2009. Leadership challenges involved in managing institutional and curriculum changes in polytechnics. In: Kouwenhoven W, Oduro G \& Nsiah-Gyabaah K (eds.). Trends in Polytechnic Education in Ghana. Amsterdam: Vrije Universiteit.

Handelzalts A 2009. Collaborative curriculum development in teacher design teams. Enschede: University of Twente.

Lieberman A \& Miller L 2005. Teachers as leaders. The Educational Forum, 153: $151-62$.

Lombard M Snyder-Duch J \& Bracken C C 2002. Content analysis in mass communication: Assessment and reporting of intercoder reliability. Human Communication Research, 28: 587-604.

McArdle K \& Coutts N 2010. Taking teachers' continuous professional development beyond reflection: Adding shared sense-making and collaborative engagement for professional renewal. Studies in Continuing Education, 32: $201-15$.
Miles M B \& Huberman A M 1994. An Expanded Source book: Qualitative data analysis. (2nd ed.). London: Sage Publications.

Millar R, Leach J, Osborne J \& Ratcliffe M 2006. Improving subject teaching: Lessons from research in science education. London: Routledge Falmer.

Mishra P, Koehler M J \& Zhao Y 2007. Introduction. In , Mishra P, Koehler M J \& Zhao Y (eds.). Communities of designers: Faculty development and technology integration. Greenwich, Connecticut: Information Age Publishing.

Nsiah-Gyabaah K 2005. Polytechnic education in Ghana: The past, the present and the future. Paper presented at the Kick-off conference, NPT/UCC Project. Cape Coast: Institute for Educational Planning and Administration.

Penuel W R, Fishman B J, Yamaguchi R \& Gallagher L P 2007. What makes professional development effective? Strategies that foster curriculum implementation. American Educational Research Journal, 44:921-58.

Simmie G M 2007. Teacher design teams - Building capacity for innovation, learning and curriculum implementation in the continuing professional development of in-career teachers. Irish Educational Studies, 26: 163-76.

Supovitz J A 2002. Developing communities of instructional practice. Teachers College Record, 104: 1591-1626.

Yin, R. K. 1993. Applications of case study research. Vol. 34. Thousand Oaks, CA: Sage. 